\title{
VINYL ACETATE-ACRYLIC ACID COPOLYMER FOR ENHANCED OIL RECOVERY
}

\author{
Gerard T. Caneba and Jay Axland \\ Department of Chemical Engineering, Michigan Technological University, \\ 1400 Townsend Drive, Houghton, MI 49931
}

\begin{abstract}
This paper pertains to the possible use of newly-synthesized vinyl acetate/acrylic acid (VA/AA) copolymer to help recover trapped crude oil, an important mineral resource. The proposed approach is to use the copolymer as a foaming surfactant (in water or brine), which will be driven by a gas, such as carbon dioxide or nitrogen. Neutralized forms of the copolymer result in an anionic surfactant, which has been found to have minimal adsorption onto the rock matrix. The neutralized VA/AA copolymers synthesized in this study are found to outperform other anionic surfactants and even more adsorbing nonionic surfactants. Due to the long chain nature of the hydrophilic groups of nonionic surfactants, they are found to produce better foams than anionic ones. Since VA/AA copolymers have long chain hydrophilic groups, it is not surprising that they are good foaming agents as well. Optical microscopy of VA/AA emulsions reveal that they form microscopic network surface structures, which are presumably due to liquid crystalline formation in macromolecular scale.
\end{abstract}




\section{Introduction}

At a time when the economic recovery is threatened by potentially high crude oil prices due to increased demand, the authors are compelled to put on-line promising new oil production technologies. Current domestic production levels have been dropping in recent years, even though it is widely known that there are still about 377 billion barrels of oil trapped within mineral rock matrices. ${ }^{1}$ New more efficient production technologies are needed to recover more of the oil originally in place (OOIP) from domestic sources.

Recently, authors developed an efficient manufacturing method for producing amphiphilic copolymers of vinyl acetate (VA) and acrylic acid (AA) at AA contents as low as 4 wt \%. A process and composition-of-matter patent has recently been submitted to the U.S. Patent and Trademark Office. ${ }^{2}$ The conceptual basis of the synthesis method is the so-called freeradical retrograde-precipitation polymerization (FRRPP) process. ${ }^{3-6}$ Early studies have indicated that these block copolymers have good foaming capabilities, especially for micellar foam-based enhanced oil recovery applications.

Aside from the widely positive oil recovery performance characteristics of VA-AA copolymers that will be described below, a review of the raw material cost structure also points to its possibility of being commercially available in the future. Table 1 below shows selling prices of some monomers and polymers in the market.

In terms of the manufacturing method used, the VA-AA-based copolymers would be similar in cost structure to those used for producing general purpose propylene and crystal polystyrene. These two materials are diluted in a solution environment, just as the VA-AA system is. Differences between polymer and monomer prices for these materials is in the $\$ 0.114-0.27 / \mathrm{lb}$ range. This is the same cost/lb associated with the formation of the VA-AA copolymers from the monomers. With a 30\% profit (based on figures from industry contacts), the cost of producing the VA-AA copolymers is in the order of $\$ 1 / 1 b$.

Based on the prices given in Table 1 and comparisons of manufacturing procedures with the method used in this paper, it is possible that poly(vinyl acetate) can be produced and sold at $\$ 2.00 / \mathrm{kg}$. If copolymerization is made with acrylic acid, $\$ 0.20 / \mathrm{kg}$ will be added to the cost (As indicated in Reference B of Table 1). This translates to an overall cost of $\$ 1.00 /$ lb of dry VAAA copolymer. Therefore, we have two approaches to the estimation of the same selling price for the VA-AA copolymers at $\$ 1.00 / 1 b$.

In $\mathrm{CO}_{2}$ flooding oil recovery operations, the VA/AA copolymers are supposed to be good foaming surfactants. Its polymeric nature results in the capability to form surfaces with relatively large radii of curvature. Since its hydrophobic part is an ester, the interface is relatively stable in the presence of hydrocarbons from the crude oil. After neutralization of the acid, the polymer is stable in brine solutions, since brine acts as a buffering agent. It is worth noting that good foaming surfactants for $\mathrm{CO}_{2}$ flooding operations have oxygenated hydrophobic groups. ${ }^{8}$ The more the oxygenated groups, the better. The drawback is that the cost of the foaming surfactant increases as well. It is possible that the VA/AA copolymer will be costeffective because the raw material cost is relatively low, while manufacturing process occurs under mild operating conditions at reasonable yields (currently up to $29 \mathrm{wt} \%$ in solution, almost $100 \%$ yield in solid). Final product can be in the form of a concentrated self-emulsion (with some alcohol) in water or as a dried solid. 
Table 1. Selling prices of some commodity monomers and polymers

\begin{tabular}{|c|c|c|}
\hline $\begin{array}{l}\text { Type of Monomer } \\
\text { or Polymer }\end{array}$ & Monomer or Polymer & Selling Price $^{\mathrm{A}}$ \\
\hline \multirow{9}{*}{$\begin{array}{l}\text { Monomer } \\
\text { Producing } \\
\text { Hydrophobic } \\
\text { Polymers }\end{array}$} & Ethylene & $\$ 0.19 / 1 b$ \\
\hline & Propylene & $\$ 0.145 / \mathrm{lb}$ \\
\hline & Vinyl Chloride & $\$ 0.20 / 1 b$ \\
\hline & Styrene & $\$ 0.23 / 1 b$ \\
\hline & Acrylonitrile & $\$ 0.385 / \mathrm{lb}$ \\
\hline & Vinyl Acetate & $\$ 0.49 / 1 \mathrm{~b}$ \\
\hline & Methyl Methacrylate & $\$ 0.60 / \mathrm{lb}$ \\
\hline & Methyl Acrylate & $\$ 0.83 / 1 \mathrm{~b}$ \\
\hline & Propylene Oxide & $\$ 0.64 / 1 b$ \\
\hline \multirow{3}{*}{$\begin{array}{l}\text { Monomers } \\
\text { Producing } \\
\text { Hydrophilic } \\
\text { Polymers }\end{array}$} & Ethylene Oxide & $\$ 0.45 / 1 \mathrm{~b}$ \\
\hline & Acrylic Acid & $\$ 0.87 / 1 \mathrm{~b}$ \\
\hline & Acrylamide & $\$ 0.80$ \\
\hline \multirow[t]{8}{*}{$\begin{array}{l}\text { Hydrophobic } \\
\text { Polymers }\end{array}$} & $\begin{array}{l}\text { Polyethylene, Low } \\
\text { Density }\end{array}$ & $\$ 0.51 / 1 \mathrm{~b}$ \\
\hline & $\begin{array}{l}\text { Polyethylene, High } \\
\text { Density }\end{array}$ & $\$ 0.43-0.49 / 1 \mathrm{~b}$ \\
\hline & $\begin{array}{l}\text { Polypropylene, General } \\
\text { Purpose }\end{array}$ & $\$ 0.31 / 1 b$ \\
\hline & Polystyrene, Crystal & $\$ 0.50 / 1 b$ \\
\hline & $\begin{array}{l}\text { Polystyrene, Expandable } \\
\text { to Foams }\end{array}$ & $\$ 0.83 / 1 b$ \\
\hline & $\begin{array}{l}\text { Polyvinylchloride, } \\
\text { General Purpose }\end{array}$ & $\$ 0.38 / 1 \mathrm{~b}$ \\
\hline & $\begin{array}{l}\text { Poly(vinyl acetate) } \\
\text { emulsion }\end{array}$ & $\begin{array}{l}\$ 1.00-2.00 / \mathrm{kg} \\
(\text { dry basis })^{\mathrm{B}}\end{array}$ \\
\hline & $\begin{array}{l}\text { Poly(vinyl acetate) beads } \\
\text { and other dry forms }\end{array}$ & $\$ 2.00-3.00 / \mathrm{kg}^{\mathrm{B}}$ \\
\hline
\end{tabular}

${ }^{A}$ Based on March 25, 2002 issue of Chemical Market Reporter

${ }^{\mathrm{B}}$ From "Concise Encyclopedia of Polymer Science and Engineering”, J.L. Kroschwitz, Ed., John Wiley and Sons, New York, 1990, pp. 1264-1270.

Estimates indicate that over the next 20 years, U.S. oil consumption will increase by $33 \%$. ${ }^{9}$ This increase amounts to an additional rate of consumption of 6 million barrels per day or 2.19 billion barrels per year. At the same time domestic production has been decreasing at the rate on 1.5 million barrels per day or 548 million barrels per year.

This increasing dependence on foreign sources of crude oil coupled with the uncertain political and military situation in the Middle East exposes the United States to future oil price volatility. The availability of improved production methods should at least have a stabilizing effect on petroleum prices, and it might also help fill in temporary foreign production shortfalls. 
For the relatively mild situation of increase of oil prices from early 1999 to late 2000 by about \$20/barrel (reaching \$30/barrel at the end of the year 2000), the effect translated to an import of roughly $\$ 80$ billion/year or a difference of $0.9 \%$ of the gross domestic product. More specific effects of this oil price increase include: ${ }^{10}$

1. Heating bills of New Englanders, who depend on heating oil, rose by $27 \%$.

2. Du Pont, a chemical company that is dependent on petrochemical products, faced an increase of $\$ 1.3$ billion in raw materials cost.

3. Georgia-Pacific's Northwest paper mill closed down and laid off 800 workers until diesel generators could be installed.

4. Trucking bankruptcies in the year 2000 was at an all-time high of 3,500 due to a $140 \%$ increase in diesel cost.

5. Farm production cost increased by $30 \%$.

In this work, the potential of using VA/AA-based copolymers as foaming surfactants in the recovery of crude oil that is trapped in various rock formations is investigated. Exploitation of new technologies for the recovery of such an important mineral resource has recently attained an urgent prominence, due to decreasing domestic production amidst increasing demand.

\section{Experimental}

Background experimental work for the formation of the VA/AA copolymer used in this work are presented elsewhere. ${ }^{2,7}$ An atmospheric static foam test method ${ }^{8}$ has been employed in order to determine comparative performance of the neutralized VA/AA surfactant. In a 25-ml graduated cylinder, $10 \mathrm{ml}$ of $0.5 \mathrm{wt} \%$ surfactant in brine $(1.5 \mathrm{X}$, which contained $15.57 \mathrm{wt} \%$ $\mathrm{NaCl}$ and $1.14 \mathrm{wt} \% \mathrm{CaCl}_{2}$ ) and $3 \mathrm{ml}$ crude oil were mixed by vertical shaking, and the foam volume measured vs. time. Two kinds of crude oil were used, a heavy one and a light one. Both were obtained from Citgo Corporation.

Emulsions from VA/AA copolymers in distilled water were viewed using an optical microscope (Zeiss Axioplan 2 from Zeiss, Thornwood, NY) at 100X and 400X magnifications. A drop of emulsion was placed between glass slides. Frames were captured using the Scion ImagePC computer software and stored onto disks as an image files. 


\section{Results and Discussion}

Table 2 shows the results of the static foaming test in comparison with literature values.

Table 2. Comparative foaming performance of VA/AA block copolymer compared with other oxygenated surfactants.

\begin{tabular}{|l|l|l|l|}
\hline Surfactant & Temperature, ${ }^{\circ} \mathrm{C}$ & Organic Material & Foam Volume, $\mathrm{ml}$ \\
\hline VA/AA (B6-1) & 67 & Bear Lake Crude $^{\mathrm{B}}$ & $4-5$ \\
\hline VA/AA (B6-1) & 20 & Bear Lake Crude & 2.3 \\
\hline Tergitol XD & 20 & Bear Lake Crude & 1.6 \\
\hline VA/AA (B6-1) & 20 & $\begin{array}{l}50 / 50 \mathrm{v} / \mathrm{v} \\
\text { Heptane/Toluene }\end{array}$ & 2 \\
\hline $\begin{array}{l}\text { Alcohol } \\
\text { Ethoxysulfate, } \\
\text { AES911-2.5S }\end{array}$ & 75 & $\begin{array}{l}50 / 50 \mathrm{v} / \mathrm{v} \\
\text { Decane/Toluene }\end{array}$ & 1 \\
\hline $\begin{array}{l}\text { Alcohol } \\
\text { Ethoxyethylsulfonate, } \\
\text { AEGS1215-12 }\end{array}$ & 75 & $\begin{array}{l}50 / 50 \mathrm{v} / \mathrm{v} \\
\text { Decane/Toluene }\end{array}$ & 0.6 \\
\hline $\begin{array}{l}\text { Alcohol } \\
\text { Ethoxysulfate, } \\
\text { AES911-5S }\end{array}$ & 75 & $\begin{array}{l}50 / 50 \mathrm{v} / \mathrm{v} \\
\text { Decane/Toluene }\end{array}$ & 0.3 \\
\hline $\begin{array}{l}\text { Alcohol } \\
\text { Ethoxyethylsulfonate, } \\
\text { AESo1215-16 }\end{array}$ & 75 & $\begin{array}{l}50 / 50 \mathrm{v} / \mathrm{v} \\
\text { Decane/Toluene }\end{array}$ & 0.2 \\
\hline $\begin{array}{l}\text { Alcohol Ethoxylate, } \\
\text { AES1215-18 }\end{array}$ & 75 & $\begin{array}{l}50 / 50 \mathrm{v} / \mathrm{v} \\
\text { Decane/Toluene }\end{array}$ & 0 \\
\hline
\end{tabular}

${ }^{\mathrm{A}}$ The Code B6-1 is the neutralized VA/AA block copolymer with $6 \mathrm{wt} \%$ AA content

${ }^{\mathrm{B}}$ This is a crude oil condensate from Bear Lake, Michigan

${ }^{\mathrm{C}}$ Tergitol XD is an ethylene oxide/propylene oxide block copolymer that is produced by Union Carbide, which is a relatively expensive nonionic surfactant

It can be seen from Table 2 that the neutralized VA/AA block copolymer outperforms (B6-1) other oxygenated surfactants. It is worth noting that the higher the proportion of oxygenated material in the surfactant the better is its foaming performance. ${ }^{8}$

In another set of experiments, light and heavy crude oil (from Citgo Corp.) were used in the static foam test column. Here, the foam volume vs. time was monitored. VA/AA-based surfactants were compared with commercial alcohol ethoxylates (Brij 78 and 721) and ethoxylated alkylphenols (Triton X-155 and X-705, and Igepal DM-880, DM-970, and CA-890), which are some of the better nonionic foaming surfactants in the market at reasonable prices. The test was conducted at $70^{\circ} \mathrm{C}$. Figure 1 shows that VA/AA surfactants (B6-1 and 6/25/02 Products) surfactant systems have higher foam volumes compared other nonionic foaming surfactants in both light and heavy crude. It is worth mentioning that the Tergitol XD surfactant 
used to generate data in Table 2 resulted in a negligible foam volume at the higher operating temperature of $70^{\circ} \mathrm{C}$.

Figure 2 shows results of comparison of foam volumes vs. time between VA/AA-based surfactants and commercially available anionic surfactants. Features of the anionic surfactants used are:

1. Triton H55 - Phosphate Esters, potassium salt

2. Rhodacal DS10 - Sodium Dodecyl Benzene Sulfonate

3. Rhodapex CO436 - Sulfates and Sulfonates of Oils and Fatty Acids

Again, VA/AA-based surfactants outperform some of their anionic counterparts. The difference here and Figure 1 is that nonionic surfactants seem to be better foam formers than anionic types. Also, it is evident that longer chain nonionics (higher numbered Brij, Triton, and Igepal) and anionics tend to be better foaming surfactants than their shorter counterparts.

Figure 3 shows a network surface structure of a VA/AA-based emulsion with $6.6 \mathrm{wt} \%$ solids. The repeat unit in the network structure is between 5 and $10 \mu \mathrm{m}$. The formation of the network or bicontinuous surfactant structure is well-established in relatively high molecular weight ethylene oxide/propylene oxide segmented block copolymer nonionic surfactants, and it has been ascribed to the formation of liquid crystalline macromolecular assemblies. ${ }^{12}$ Upon dilution, the emulsion showed $10 \mu \mathrm{m}$ spherical domains that could form aggregates up to about $60 \mu \mathrm{m}$ in size (Figure 4). In Figure 5, bubble surfaces are shown with the network surfactant structure.

Gas-flooding enhanced oil recovery has been commercialized in the 1980s, and it has become a great success story. ${ }^{13}$ The continued success depends on the availability of betterperforming and lower cost surfactants. Estimates vary, but the amount of oil recoverable from gas-flooding operations is in the tens of billions of barrels here in the United States. The incremental cost of surfactant-flooding operations had been pegged at $\$ 8-12 /$ barrel of oil, ${ }^{14}$ in which a substantial fraction of that is the cost of surfactants and other chemicals. These figures translate to possible demand for surfactants in the order of billions of pounds per year. More efficient, lower cost surfactants can amount to billions of dollars in savings, and it may involve less surfactant use per barrel of oil recovered.

\section{Conclusion}

Newly synthesized vinyl acetate-acrylic acid-based copolymers have been shown to be attractive foaming surfactants for the recovery of crude oil that is trapped within rock matrices. Results were obtained, based on static foaming tests, and optical microscopy of emulsions. These new copolymer materials could put micellar foam flooding in the forefront of enhanced oil recovery, if fully developed. 


\section{References}

1. Obtained from http://www.fe.doe.gov/oil_gas/res_efficiency.shtml

2. Caneba, G.T. and Dar, Y., 2002, "Free Radical Retrograde Precipitation Copolymers and Process for making Same", submitted to U.S. Patent and Trademark Office, January.

3. Caneba, G.T., 1992, "Free-Radical Retrograde-Precipitation Polymerization Process", U.S. Patent No. 5,173,551, December;

4. Caneba, G. T., 1992, Adv. Polym. Tech., 11, 277-286;

5. Aggarwal, A., R. Saxena, B. Wang, and G. T. Caneba, 1996, J. App. Polym. Sci., 62, 20392051;

6. Wang, B., Y. Dar, L. Shi, and G. T. Caneba, 1999, J. App. Polym. Sci., 71, 61-74.

7. Caneba, G.T., 2002, Proceedings of the American Institute of Chemical Engineers Annual Meeting, Indianapolis, IN, November 3-8.

8. Borchardt, J.K., Bright, D.B., Dickson, M.K., and Wellington, S.L., 1988, "Surfactants for Carbon Dioxide Foam Flooding", in: Surfactant-Based Mobility Control - Progress in Miscible-Flood Enhanced Oil Recovery, D.H. Smith, Ed., ACS Symposium Series, 373, Washington, D.C., Chapter 8.

9. "National Energy Policy: Report of the National Energy Policy Development Group", U.S. Government Printing Office, Washington, D.C., May, 2001, p. x.

10. Ibid., Chapter 2.

11. Obtained from http://news.ft.com

12. Chu, B. and Z. Zhao, 1996, "Nonionic Surfactants", Nace Vaugn, Ed., Marcel Dekker, NY, pp. 67-143.

13. Klins, M.A. and C.P. Bardon, 1991, "Carbon Dioxide Flooding", in:Basic Concepts in Enhanced Oil Recovery Processes, M. Baviere, Ed., Elsevier Applid Science, New York., pp.215-240.

14. Obtained from http://fe.doe.gov/oil_gas_res_efficiency/res_progareas.shtml 


\section{Acknowledgements}

The authors wish to acknowledge Mr. David Colquhoun in the research group of Dr. Susan Bagley in the Michigan Tech Department of Biological Sciences, for his assistance in the use of their optical microscope for viewing the surfaces of our VA/AA-based emulsions and foams. 


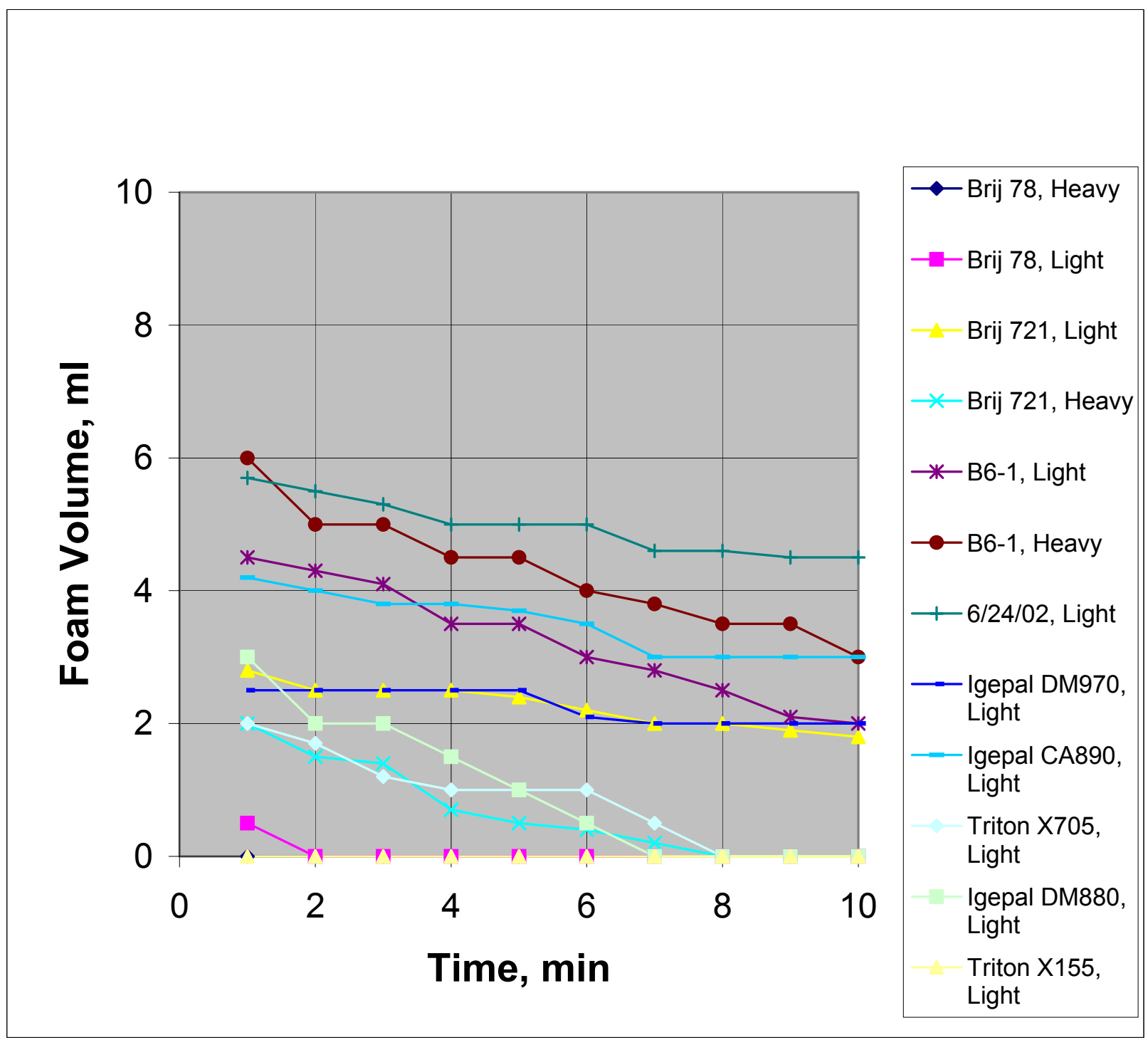

Figure 1. Static foam volume vs. time for the VA/AA-based copolymers (B6-1 and 6/24/02 Emulsions) and commercially available nonionic surfactants (Brij, Triton, and Igepal surfactants) at $70^{\circ} \mathrm{C}$. Light and heavy crude oil was used in this test. 


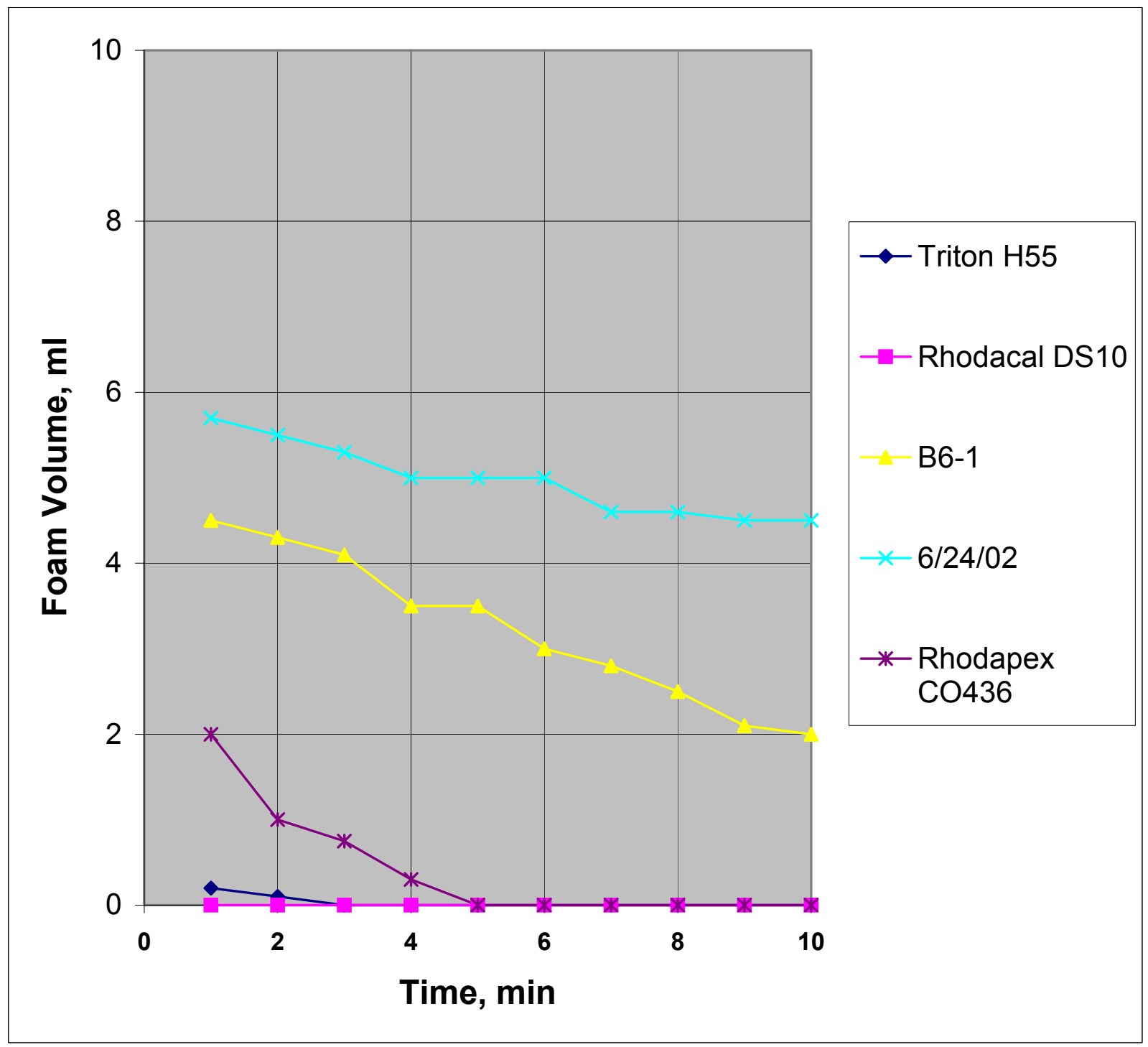

Figure 2. Static foam volume vs. time for the VA/AA-based copolymers (B6-1 and 6/24/02 Emulsions) and commercially available anionic surfactants (Triton, Rhodacal, and Rhodapex surfactants) at $70^{\circ} \mathrm{C}$. Light crude oil was used in this test. 


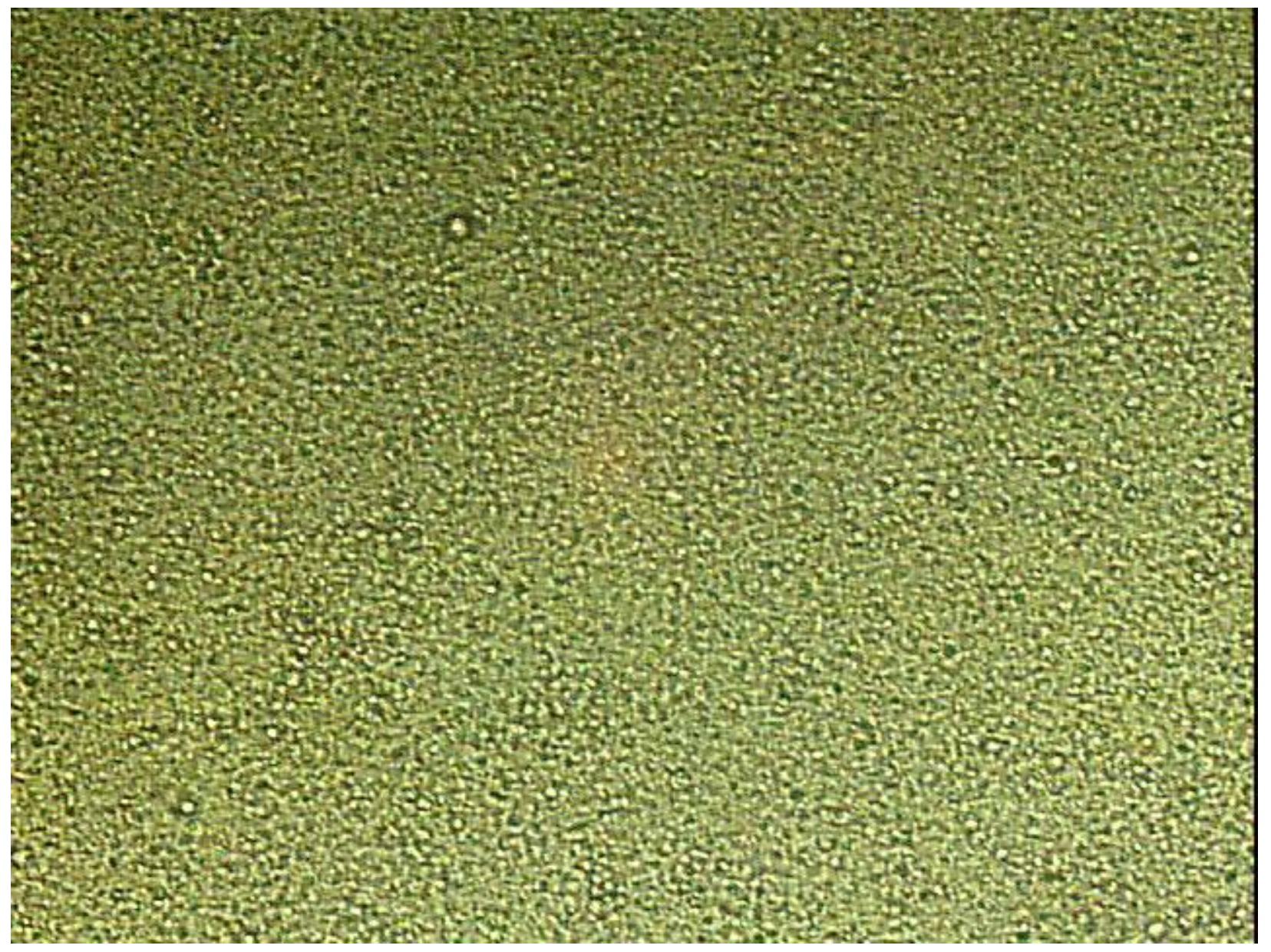

Figure 3. Optical micrograph of a surface of a VA/AA-based emulsion (6.6 wt \% solids) at 400X magnification, showing a bicontinuous network structure with 5-10 $\mu \mathrm{m}$ open cells. 


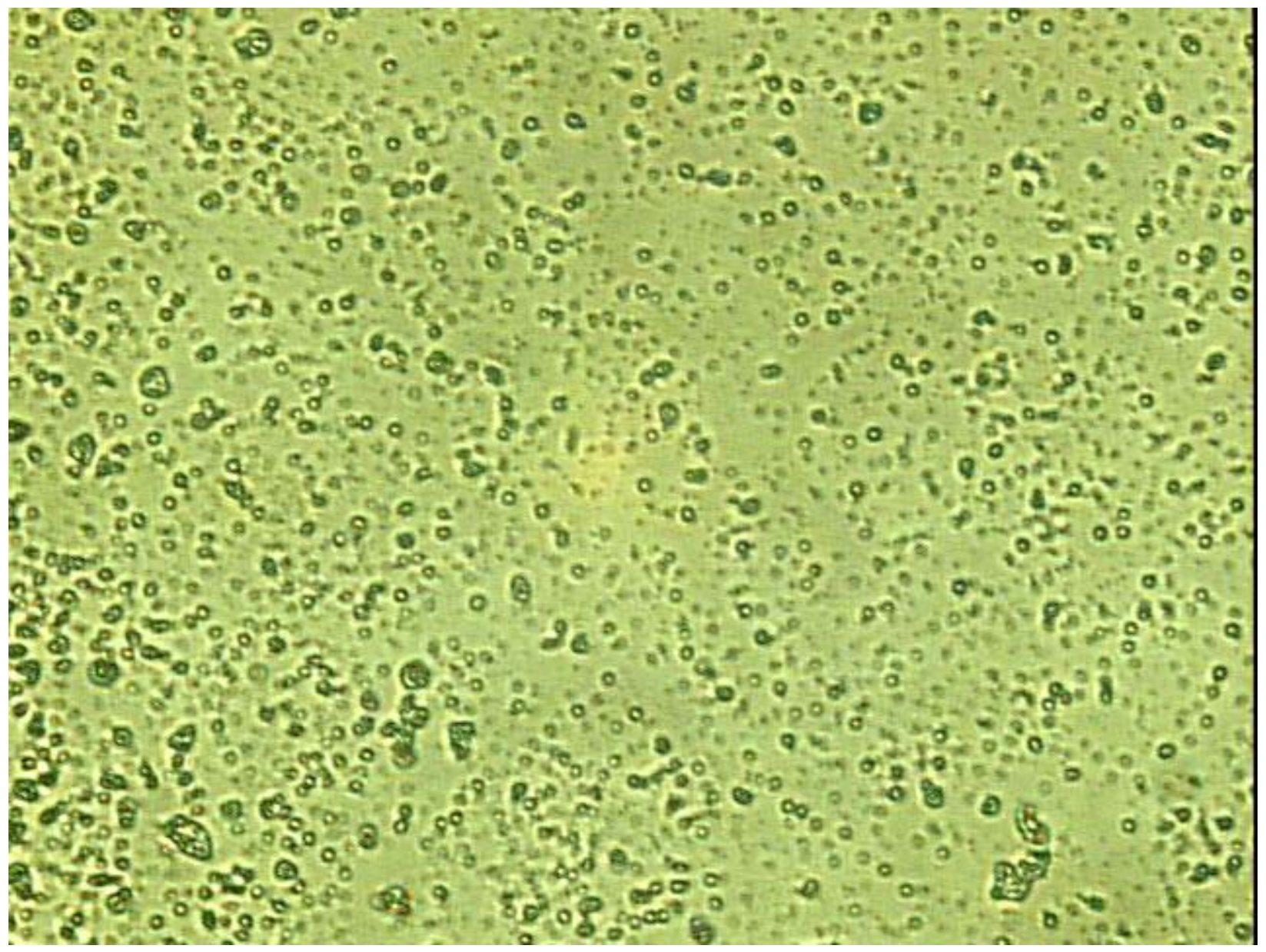

Figure 4. Optical micrograph of a surface of a VA/AA-based diluted emulsion (from $6.6 \mathrm{wt} \%$ solids) at $400 \mathrm{X}$ magnification, showing about $10 \mu \mathrm{m}$ spherical domains and aggregates up to about $60 \mu \mathrm{m}$ in size. 


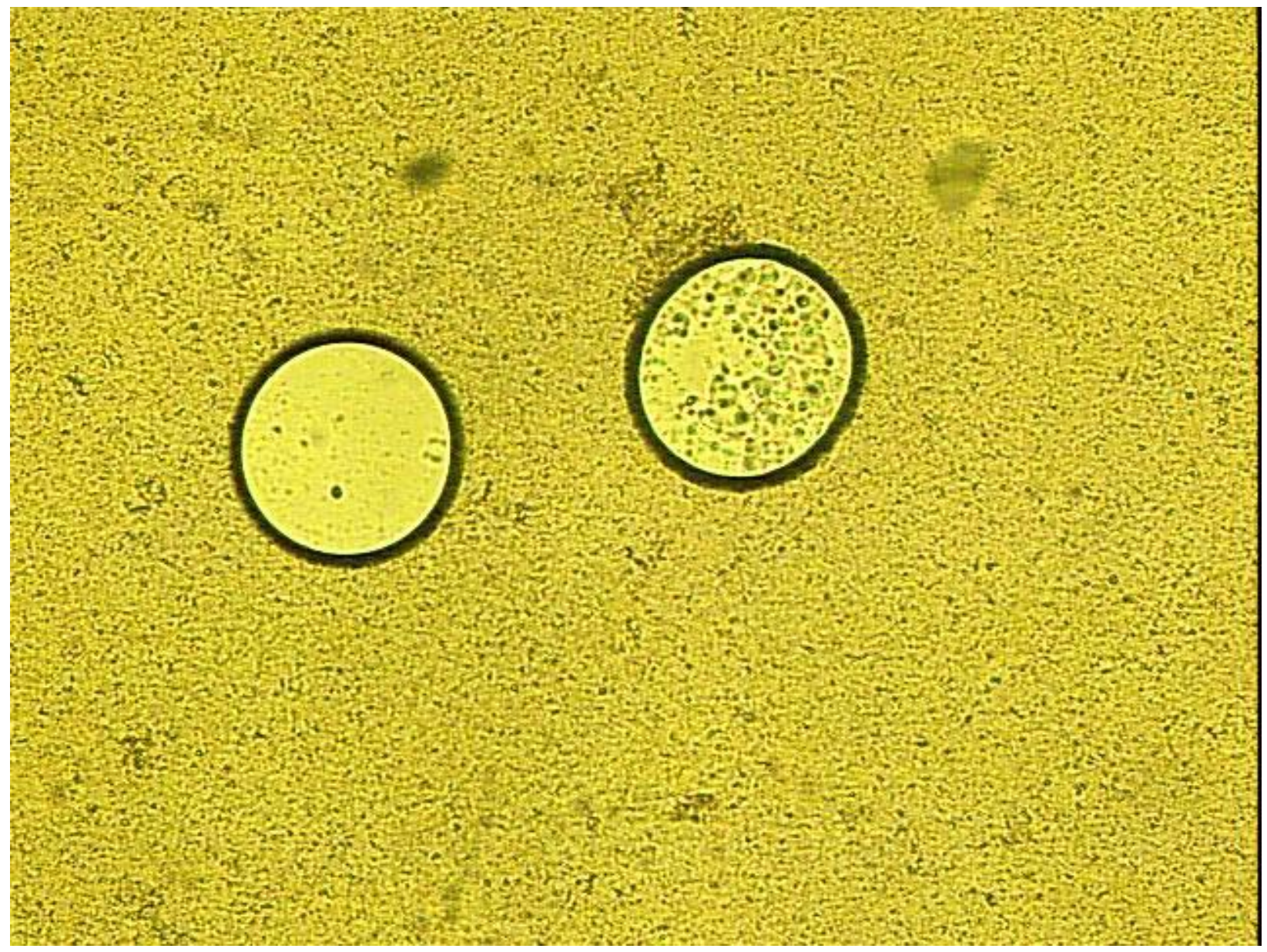

Figure 5. Optical micrograph of a surface of a VA/AA-based diluted emulsion (from $6.6 \mathrm{wt} \%$ solids) at 100X magnification, showing a surface of a bubble that has a bicontinuous network structure. 